\title{
Effect of Season and Lactation Number on Milk Production of Holstein Friesian Cows in Kabul Bini-Hesar Dairy Farm
}

\author{
Emal Habibi' ${ }^{1}$ M. Ibrahim Qasimi ${ }^{*}$, Noorullah Ahmadzai ${ }^{1}$, Nasrin Stanikzai ${ }^{2}$, M. Zaher Sakha ${ }^{3}$ \\ ${ }^{1}$ Department of Animal Production, Faculty of Veterinary Sciences, Kabul University, Kabul, Afghanistan \\ ${ }^{2}$ Department of Preclinic, Faculty of Veterinary Sciences, Kabul University, Kabul, Afghanistan \\ ${ }^{3}$ Department of Food Hygiene and Technology, Faculty of Veterinary Sciences, Kabul University, Kabul, Afghanistan \\ Email: ^iqasimi@Ku.edu.af
}

How to cite this paper: Habibi, E., Qasimi, M.I., Ahmadzai, N., Stanikzai, N. and Sakha, M.Z. (2021) Effect of Season and Lactation Number on Milk Production of Holstein Friesian Cows in Kabul Bini-Hesar Dairy Farm. Open Journal of Animal Sciences, 11, 369-375.

https://doi.org/10.4236/ojas.2021.113026

Received: February 8, 2021

Accepted: June 4, 2021

Published: June 7, 2021

Copyright ( 2021 by author(s) and Scientific Research Publishing Inc. This work is licensed under the Creative Commons Attribution International License (CC BY 4.0).

http://creativecommons.org/licenses/by/4.0/ (c) (i) Open Access

\begin{abstract}
The present study was designed to investigate the effects of season and lactation number on milk yields in Holstein dairy cows at Kabul Bini Hesar Dairy Farm. For this purpose, data were collected from the dairy farm herd book records during 1392-1393 (2013-2014). Considering the milk yield stages of the cows, the total milk production was highest during the spring season $18,454.95 \pm 33 \mathrm{~L}$ followed by summer $17,060.85 \pm 34.5 \mathrm{~L}$ while the lowest milk production obtained in winter $16,398.45 \pm 31.5 \mathrm{~L}$. Moreover, the average daily milk production of the cows was significantly different $(\mathrm{p}<0.05)$ between the 1st, 2nd and 3rd lactations and the amounts were $12.04 \pm 0.7,13.24$ \pm 0.8 and $14.10 \pm 0.6 \mathrm{~L} /$ day respectively. Milk yields of individual cows were gradually increased from 1st to 3rd lactation. The highest milk yield was recorded in 3rd lactation and the lowest was in 1st. From this study it was found that season and lactation number had a significant effect on the milk quantity.
\end{abstract}

\section{Keywords}

Season, Lactation Number, Milk, Cows, Dairy Farm

\section{Introduction}

Afghanistan is an agricultural country where the majority of its people are engaged in agriculture and livestock [1]. The majority of the Afghan population lives in rural areas, where poverty and deprivation are the most severe. Since almost all rural households depended directly or indirectly on agriculture and livestock and they earn their daily income from these sectors [2]. Cattle keeping 
in Afghanistan has been promoted since ancient times and cattle are widely used for its products such as meat, milk and power. However, the cattle performance being considerably low in the country might be due to improper nutrition and management or weather condition. Therefore, their carcass yield is low, the duration of lactation is short and the amount of milk they produce during their lactation periods is not enough. However, the role of the cow is considered valuable and strengthening the national economy [3]. Climate factors such as air temperature and humidity often limit animal performance [4], like reduction in milk yield, feed intake [5], intestinal metabolisms and reproduction [6]. Milk yield in a dairy cow is closely related to the animal's genetic merits and environmental factors [7] [8]. Among the environmental factors, the roles of managements, nutrition and hygiene seem to be crucial [9]. Moreover, [10] and [11] reported that the animal breed, stage of lactation, parity and milking frequency also influence performance production.

Afghanistan is characterized by having a high range of maximum and minimum temperature. Afghanistan is an agricultural landlocked country where majority of its population is engaged in agriculture and livestock husbandry [12]. The Hindu Kush Mountains which runs from northeast to southwest, divides the country into different natural regions with totally different temperatures and precipitation rates [13]. The climate varies considerably between arid and semiarid with hot summers and cold winters. The lowest mean annual precipitation occurs in the southwestern plateau region and the highest precipitation occurs in the northeastern Hindu Kush Mountain's foothill regions ranging from about $30 \mathrm{~mm}$ to $1000 \mathrm{~mm}$ respectively. Furthermore, the mean annual temperature is different between the regions ranging from $0.7^{\circ} \mathrm{C}$ in Hindu Kush mountains to $23.3^{\circ} \mathrm{C}$ toward southern plateau [12] [13]. The climate change in Kabul province is of course extremely continental, cold winters, and dry hot and dusty summers. The temperature changes little from day to day. The monthly average temperature in Kabul province is in Jan-2.3, Feb 0.7, Mar 6.3, Apr 12.8, May 17.3, Jun 22.8 Jul 25.0, Aug 24.1, Sep 19.7, Oct 13.1, Nov 5.9 and Dec 0.6 respectively [12].

Dairy cows need suitable temperatures of between $5^{\circ} \mathrm{C}$ and $25^{\circ} \mathrm{C}$. At temperatures above $26^{\circ} \mathrm{C}$, the cow reaches a point where she cannot cool herself and suffers from heat stress [6]. In order to increase the yield level, it is necessary to optimize the environmental condition and to improve the genetic structure of the animals. In order to enhance productivity of a dairy animal, it is necessary to develop an understanding of the factors affecting its milk production [7]. The objective of this study was to determine the effect of Season and lactation number on Milk production of Holstein Friesian Cows in Kabul Bini Hesar Dairy Farm, Afghanistan.

\section{Materials and Methods}

Bini hesar dairy farm which is located in Kabul city is the only governmental 
farm established in 1958 by the aid of France for improvement of genetic potential of the local dairy cattle breeds in Afghanistan. Currently about 80 Holstein-Friesian cows were kept for milk production and breeding. The genetic materials were collected from the bulls were send to the breeding stations around the country. In this research, 15 Holstein cows were studied to evaluate the annual quantity of milk production in different season and lactation number in Bini Hesar Dairy Farm. These cows were selected based on their date and the number of calving obtained from the farm record book. The daily milk production data of the cattle which was recorded within the years 1392-1393 (correspondent to 2013-2014) was analyzed based on the four-season spring (April to June), summer (July to September), autumn (October to December) and winter (January to March) as previously described [14]. Moreover, for further information about the management and nutritional conditions, related questionnaires and individual observation were done. Without taking into consideration the age and body condition of the cows, management and raising. Feeding conditions for all cows were the same but in the winter season all the cows were fed with concentrate ( $3-4 \mathrm{~kg}$ cotton cake + silage and dried fodder) and in summer season the cows were taken into the pasture for grazing. Water was available for all cow ad libitum. It's obvious that we were faced with many limitations during this research such as lack of synchronized calving cattle, absence of enough cows in the same age and lack of such a dairy farm in Kabul province. Furthermore, transportation and other facilities for doing research as well.

Data were statistically analyzed by analysis of variance (ANOVA) and Tukey test by using SPSS software 16.0 (SPSS Inc., Chicago, IL) for finding the difference between the seasons. The significance level adopted was $\mathrm{p}<0.05$.

\section{Results}

\subsection{Effect of Season on Milk Yield}

By considering the cows' lactation stage, the effect of season was significant on milk yield of dairy cows. The average milk production of Holstein Frisian breed in different seasons was estimated and it was noticed that the highest average of $18,454.95 \pm 33 \mathrm{~L}$ milk production in spring season followed by 17,060.85 \pm 34.5 $\mathrm{L}$ in summer and lowest in winter, as $16,398.45 \pm 31.5 \mathrm{~L}$ respectively. The effects of season on the milk production are presented in Table 1.

\subsection{Effect of Lactation Number on Average of Daily Milk Yield}

The average daily milk yield of Holstein cows at different lactation number are presented in Table 2. It was found that the average daily milk yield of cows at 1st, $2 \mathrm{nd}$ and 3 rd lactation were $12.04 \pm 0.7,13.24 \pm 0.8,14.10 \pm 0.6 \mathrm{~L}$ respectively. Statistical analysis showed that there was significant difference $(\mathrm{p}<0.05)$ within the daily milk yield of different lactations. Milk yield increased gradually from 1st to 3rd lactation. The highest milk yield was recorded in 3rd lactation $(14.10 \pm 0.6 \mathrm{~L})$ and lowest was in 1st lactation $(12.04 \pm 0.7 \mathrm{~L})$. Moreover, lactation number had significant effect $(\mathrm{p}<0.05)$ on daily milk yields of dairy cows. 
Table 1. Average of milk production according to season of year.

\begin{tabular}{ccc}
\hline Season & Number of animals & Average Milk Yield (L/season) \\
\hline Spring & 15 & $18,454.95 \pm 33^{\text {a* }}$ \\
Summer & 15 & $17,060.85 \pm 34.5$ \\
Winter & 15 & $16,398.45 \pm 31.5$ \\
\hline
\end{tabular}

${ }^{\star}$ Data were represented as mean $\pm \mathrm{SE}$.

Table 2. Average of daily milk production according to lactation number.

\begin{tabular}{ccccc}
\hline Lactation & Sample size & Mean \pm SE & MMY $(\mathrm{L})^{\star}$ & MMY $(\mathrm{L})^{\ddagger}$ \\
\hline 1 & 5 & $12.04 \pm 0.7$ & 8.8 & 12.9 \\
2 & 4 & $13.24 \pm 0.8^{\mathrm{a}}$ & 9.2 & 13.5 \\
3 & 6 & $14.10 \pm 0.6^{\mathrm{b}}$ & 9.6 & 14.3 \\
\hline
\end{tabular}

${ }^{\star}$ Minimum milk yield; ${ }^{\ddagger}$ Maximum milk yield.

\section{Discussion}

We found that season of the year had significant effects on milk production of dairy cattle in Bini Hesar Dairy Farm. The similar results were previously reported [8] [15] [16]. The season had a significant effect on the milk yields, the highest average of milk production was obtained during the spring season followed by summer and lowest in winter. The results of this study align with [17] who reported the highest milk production was obtained during rainy season, $3350.00 \mathrm{~kg}$, followed by summer $3116.70 \mathrm{~kg}$ while the lowest average milk production was obtained in winter $2925.50 \mathrm{~kg}$. [18] also reported a similar result more milk was produced during the spring than winter season in all breeds. Milk yield increment during the spring season is probably due to favorable air temperature and fresh fodder availability. Although dietary regimen of dairy cow was similar in spring and summer seasons, milk production was not as much as spring season. [17] reported that seasonal variation of the milk yield is due to the milk secretion stimulation by the green fodder, which is fed to cows during the rainy and summer seasons of the year and number of cows milked. Moreover, lower milk production in summer and winter seasons are might be due to air temperature, because the temperature is lower or higher than the thermoneutral comfort zoon for cattle. [6] reported that dairy cows under minimum or maximum air temperature than suitable temperature not only reduce milk quantity but also effect on milk protein and fat.

Multiple studies have been distributed the effect of lactation number on milk yield of dairy cows. Basically, all the studies have established that milk yield increases with increasing lactation number [19] [20]. The present study result showed lower milk yield in 1st lactation cows, in the early lactation, the animals are not in the productive stage and they remain in growing stage and at the same time their mammary gland and vein are not well developed at that stage [21]. Also, current study results exhibited greater milk yield in the 3rd lactation. This 
present study results agreed with [22] and [21] they have reported generally maximum milk yield is expected when the cows have grown fully at about 3rd of 4 th lactation. In previous report, 305-day milk yield of cows with 2 lactations was $17 \%$ greater than that of first lactation cows, and third lactation cows produced 5.5\% more milk than second lactation cows [20]. Furthermore [23] also reported in cows as lactation number from calving increased the total milk yield increased. Overall our current results exhibited the increased milk yield with increasing lactation number, which may be due to increasing development and size of the udder with a resulting increase of secretory cells [24]. Other reasons for high milk yield may be increased parity, which plays a significant role in the control of the tissue mobilization between the primiparous and multiparous cows and includes increasing body weight of dairy cows over that of first lactation [25].

\section{Conclusion}

From the above findings, it may be concluded that seasonal variation and lactation number affect the milk yield of dairy cows. So, the milk yield of dairy cows in Bini Hesar Dairy Farm varies in different seasons and lactation numbers. The milk yield of dairy cows in the Bini Hesar Dairy Farm is at a high peak in spring compared to summer and winter seasons. Also, the milk yield of dairy cows is high at 3rd lactation and low at 1st lactation. The milk yield of Holstein dairy cows is at a low level in the Bini Hesar Dairy Farm. Food with good quantity and quality increases the milk yield of dairy cows.

\section{Acknowledgements}

The authors would like to thank the head and staff of Bini Hesar Dairy Farm for allowing us to use the record data of their dairy farm.

\section{Conflicts of Interest}

The authors declare no conflicts of interest regarding the publication of this paper.

\section{References}

[1] Bolton, L. (2019) Agriculture in Afghanistan-Economic Sustainability and Sub-Sector Viability. K4D Helpdesk Report 574. Institute of Development Studies, Brighton, 1-12.

[2] Muradi, A.J. and Boz, I. (2018) The Contribution of Agriculture Sector in the Economy of Afghanistan. International Journal of Scientific and Management, 6, 750-755. https://doi.org/10.18535/ijsrm/v6i10.em04

[3] Ahmad, N.A. (1991) Raising and Production of Large Domestic Animals. In: Text Book, Ministry of Higher Education, 23.

[4] Sharma, K.C., Rodriguez, L.A., Mekonnen, G., Wilcox, C.J., Bachman, K.C. and Collier, R.J. (1983) Climatological and Genetic Effects on Milk Composition and Yield. Journal of Dairy Science, 66, 119-126. 
https://doi.org/10.3168/jds.S0022-0302(83)81762-7

[5] Collier, R.J., Beede, D.K., Thatcher, W.W., Israel, L.A. and Wilcox, C.J. (1982) Influences of Environmental and Its Modification on Dairy Animal and Production. Journal of Dairy Science, 65, 2213-2227. https://doi.org/10.3168/jds.S0022-0302(82)82484-3

[6] Nam, K.T., Kim, K.H., Nam, I.S., Abanto, O.D. and Hwang, S.G. (2009) Seasonal and Regional Effects on Milk Composition of Dairy Cows in South Korea. Journal of Animal Science and Technology, 51, 537-542. https://doi.org/10.5187/JAST.2009.51.6.537

[7] Zukiewicz, A., Gtzesiak, W., Szatkowska, I., Blaszcyk, P. and Dybus, A. (2012) Genetics Factors of Milk Yield in Dairy Cattle-Advances in the Quest for Universal Markers. Israel Journal of Veterinary Medicine, 67, 82-91.

[8] Coelho, K.O., Machado, P.F., Coldebella, A., Meyer, P.M., Cassoli, L.D. and Rodrigues, P.H.M. (2004) Factors Affecting Milk Yield at Peak and during Current Lactation of Holstein Cows. Journal of Animal and Feed Science, 13, 475-478. https://doi.org/10.22358/jafs/73969/2004

[9] Wondifraw, Z., Thombre, B.M. and Bainwad D.V. (2013) Effect of Non-Genetic Factors on Milk Production of Holstein Friesian $\times$ Deoni Crossbred Cows. International Journal of Livestock Production, 4, 106-112. https://doi.org/10.5897/IJLP2013.0173

[10] Azad, M.A., Hasanuzzaman, M., Azizunnesa, Shil, G.C. and Barik M.A. (2007) Milk production Trend, Milk Quality and Seasonal Effect on It at Baghabarighat Milk Shed Area, Bangladesh. Pakistan Journal of Nutrition, 6, 363-365.

https://doi.org/10.3923/pjn.2007.363.365

[11] Shibru, D., Tamir, B., Kasa, F. and Goshu, G. (2019) Effect of Season, Parity, Exotic Gene Level and Lactation Stage in Milk Yield and Composition of Holstein Friesian Crosses in Central Highlands of Ethiopia. European Journal of Experimental Biology, 9, Article No. 15.

[12] Aich, V., Akhundzadah, N.A., Knuerr, A., Khoshbeen, A.J., Hattermann, F., Paeth, H., Scanlon, A. and Paton, E.N. (2017) Climate Change in Afghanistan Deduced from Reanalysis and Coordinated Regional Climate Downscaling Experiment (CORDEX)-South Asia Simulations. Climate, 5, Article No. 38.

https://doi.org/10.3390/cli5020038

[13] Qutbudin, I., Shiru, M.S., Sharafati, A., Ahmed, K., Al-Ansari, N., Yaseen, Z.M., Shahid, S. and Wang, X. (2019) Seasonal Drought Pattern Changes Due to Climate Variability: Case Study in Afghanistan. Water, 11, Article No. 1096. https://doi.org/10.3390/w11051096

[14] Singa, V.P., Dubey, M. and Chaubey, A.K. (2014) Seasonal Influence on Milk Production Performance in Different Breed of Dairy Cows. Environment \& Ecology, 33, 371-374.

[15] Mostert, B.E., Theron, H.E. and Kanfer F.H.J. (2001) The Effect of Calving Season and Age at Calving on Production Traits of South African Dairy Cattle. South African Journal of Animal Science, 31, 205-214. https://doi.org/10.4314/sajas.v31i3.3795

[16] Susanto, A., Hakim L, Suyadi. and Nurgiartiningsih V.M.A. (2019) Environment (Year and Season of Birth) Effects on First-Lactation Milk Yield of Dairy Cows. IOP Conference Series Earth and Environmental Science, 372, Article ID: 012010. https://doi.org/10.1088/1755-1315/372/1/012010

[17] Zaman, M.A., Ara, A. and Haque, M.N. (2016) Effect of Season on Production and Quality of Milk of Crossbred Dairy Cows at Sylhet District Government Dairy Farm 
in Bangladesh. Bangladesh Journal of Animal Science, 45, 52-57. https://doi.org/10.3329/bjas.v45i3.31046

[18] Nantapo, C.T.W. and Muchenje, V. (2013) Winter and Spring Variation in Daily Milk Yield and Mineral Composition of Jersey, Friesian Cows and Their Crosses under a Pasture-Based Dairy System. South African Journal of Animal Science, 43, S17-S21. https://doi.org/10.4314/sajas.v43i5.3

[19] Cilek, S. (2009) Milk Yield Traits of Holstein Cows Raised at Polatli State Farm in Turkey. Journal of Animal and Veterinary Advances, 8, 6-10.

[20] Mellado, M., Antonio-Chirino, E., Meza-Herrera, C., Veliz, F.G., Arevalo, J.R., Mellado, J. and de Santiago, A. (2011) Effect of Lactation Number, Year, and Season of Initiation of Lactation on Milk Yield of Cows Hormonally Induced into Lactation and Treated with Recombinant Bovine Somatotropin. Journal of Dairy Science, 94, 4524-4530. https://doi.org/10.3168/jds.2011-4152

[21] Ahmad, S., Hossain, F.M.A. and Islam, N. (2011) Effect of Lactation Number and Different Stage of Lactation on Milk Yield of Indigenous and Crossbred Cows in Bangladesh. International Journal of Natural Sciences, 1, 31-34.

[22] Ayalew, W., Aliy, M. and Neguessie, E. (2015) Milk Production Performance of Holstein Friesian Dairy Cows at Holetta Bull Dam Farm, Ethiopia. Livestock Research for Development, 27, Article No. 173.

[23] Ray, D.E., Halabach, T.J. and Armstrong, D.V. (1992) Season and Lactation Number Effects on Milk Production and Reproduction of Dairy Cattle in Arizona. Journal of Dairy Science, 75, 2976-2983. https://doi.org/10.3168/jds.S0022-0302(92)78061-8

[24] Sorensen, M.T., Norgaard, J.V., Theil, P.K., Vestergaard, M. and SeJrsen, K. (2006) Cell Turnover and Activity in Mammary Tissue during Lactation and the Dry Period in Dairy Cows. Journal of Dairy Science, 89, 4623-4639. https://doi.org/10.3168/jds.S0022-0302(06)72513-9

[25] Wathes, D.C, Cheng, Z., Bourne, N., Taylor, V.J., Coffey M.P. and Brotherstone, S. (2007) Differences between Primiparous and Multiparous Dairy Cows in the Inter-Relationships between Metabolic Traits, Milk Yield and Body Condition Score in the Periparturient Period. Domestic Animal Endocrinology, 33, 203-205.

https://doi.org/10.1016/j.domaniend.2006.05.004 